\title{
Species trait shifts in vegetation and soil seed bank during fen degradation
}

\author{
Agata Klimkowska · Renée M. Bekker • \\ Rudy Van Diggelen · Wiktor Kotowski
}

Received: 14 March 2008/Accepted: 17 June 2009/Published online: 11 July 2009

(C) The Author(s) 2009. This article is published with open access at Springerlink.com

\begin{abstract}
Fens in Central Europe are characterised by waterlogged organic substrate and low productivity. Human-induced changes due to drainage and mowing lead to changes in plant species composition from natural fen communities to fen meadows and later to over-drained, degraded meadows. Moderate drainage leads to increased vegetation productivity, and severe drainage results in frequent soil
\end{abstract}

A. Klimkowska · R. M. Bekker

Community and Conservation Ecology Group, Centre for Ecological and Evolutionary Studies, University of Groningen, P.O. Box 14, 9750 AA Haren, The Netherlands

\section{A. Klimkowska}

The Institute for Land Reclamation and Grassland Farming, Falenty, Al. Hrabska 3, 05-090 Raszyn, Poland

R. Van Diggelen

Department of Biology, Ecosystem Management

Research Group, University of Antwerpen,

Universiteitsplein 1, 2610 Wilrijk, Belgium

W. Kotowski

Department of Plant Ecology and Environmental Conservation, Institute of Botany, University of Warsaw, Al. Ujazdowskie 4, 00-478 Warszawa, Poland

\section{A. Klimkowska ( $\square)$}

Alterra, Centrum Landscape, Postbus 47, 6700 AA Wageningen, The Netherlands

e-mail: Agata.Klimkowska@wur.nl disturbances and less plant growth. In the present article, we analyse changes in plant trait combinations in the vegetation and the soil seed bank as well as changes in the seed bank types along gradient of drainage intensity. We hypothesize that an increase in productivity enhances traits related to persistence and that frequent disturbance selects for regeneration traits. We use multivariate statistics to analyse data from three disturbance levels: undisturbed fen, slightly drained fen meadow and severely drained degraded meadow. We found that the abundance of plants regenerating from seeds and accumulating persistent seed banks was increasing with degradation level, while plants reproducing vegetatively were gradually eliminated along the same trajectory. Plants with strong resprouting abilities increased during degradation. We also found that shifts in trait combinations were similar in the aboveground vegetation and in soil seed banks. We found that the density of short-term persistent seeds in the soil is highest in fen meadows and the density of long-term persistent seeds is highest in degraded meadows. The increase in abundance of species with strong regeneration traits at the cost of species with persistencerelated traits has negative consequences for the restoration prospects of severely degraded sites.

Keywords Drainage - Anthropogenic disturbance . Shifts in plant trait spectra - Seed bank longevity . Clonal growth 


\section{Introduction}

Human-induced environmental changes often conflict with biodiversity conservation targets. Mires, especially fens, are severely threatened (Van Diggelen et al. 2006) and knowledge on community processes that occur during fen degradation is, therefore, of great importance. In Central Europe, natural fens are scarce and cover limited area (Joosten and Clarke 2002), thus their existence is threatened to larger extent than this of meadows on mineral soils. The present study contributes to this knowledge by analysing shifts in plant trait spectra and trait combinations along the ecological gradient from undisturbed fens to severely degraded meadows.

This gradient develops over time because of increasing drainage intensity (large-scale, chronic disturbance), leading to shifts in abiotic conditions through physical and chemical changes in the peat body (Okruszko et al. 1999; Zeitz and Velty 2002; Okruszko and Ilnicki 2003). The endpoint of this process is the formation of a substrate with little capillary water rise and almost no water storage capacity (Okruszko 1957; Kajak and Okruszko 1990), leading to water shortage in the rooting zone during the dry season. Parallel to the changes in abiotic conditions are the vegetation changes from undisturbed fens via fen meadows to species-poor ruderal grasslands (Faliński 1966; Jasnowski 1972; Okruszko 1977; Okruszko et al. 1999; Kucharski 2000). Analyses of changes in species frequency in larger areas and over periods of several decades show clear shifts, mostly from stress-tolerant species towards fastgrowing competitors and a change from vegetative growth to generative reproduction (Thompson 1994; Bullock et al. 1995; Grime 2002; Van Diggelen et al. 2005). Unfortunately, the majority of studies on this topic was carried out in mesic grasslands. The impact of environmental changes on trait syndromes may be different in fens, where complex gradients in nutrient and water availability, anoxia and disturbance interact with each other and may favour other trait combinations than the ones mentioned above.

During the fen degradation process, plants are subject to simultaneous shifts in several constraints: nutrient availability, degree of anoxia, water availability, temperature regime (Succow and Joosten 2001) and disturbance intensity (sensu Grime 1979). These changes may run parallel or in different directions. In undrained fens, nutrient availability is low and most plants will experience almost constant root anoxia but water is freely available and disturbances such as grazing or mowing are rare (De Mars et al. 1996; Middleton et al. 2006). Stresses related to root anoxia (Lenssen et al. 1998, Lenssen et al. 2003) and low nutrient availability (Verhoeven et al. 1993; Van Duren et al. 1997; Olde Venterink et al. 2002) are relieved during the transition from fen to fen meadow. Water availability is optimal for plant growth and the disturbance level is intermediate. These favourable conditions lead to an increase in productivity and to a shift from competition for nutrients to competition for light (Kotowski and Van Diggelen 2004). This results in the elimination of the least competitive species (Grime 1973; Bakker and Olff 1995). We assumed that management has less impact than degradation, although it affects the competitive interactions in the vegetation and, indirectly, the soil seed bank. In degraded meadows, plants are subject to high stress levels with respect to water and nutrient availability, but root anoxia does not occur. The productivity decreases (Banaszuk et al. 1996; Kucharski and Pisarek 1996; Kucharski, 2000) and soil disturbances are common, mainly from animal trampling and rooting (Menge and Sutherland 1987; Welander 2000; Sousa 1984).

Plant traits and their combinations rather than species identities are the units that are affected by ecological processes (Keddy 1992; Lavorel et al. 1997; Diaz et al. 2002). Changes in essential constraints alter selection pressure and lead to the responses in species combinations, by filtering plants with particular sets of traits from the available species pool (Table 1; Lavorel et al. 1997; Lavorel and Garnier 2002). The ecological filters constitute the assembly rules, which determine ecosystem structure and functions. Understanding these rules is very important for ecosystem restoration (Temperton et al. 2004). Grime (2002) proposed two main factors controlling species assembly in herbaceous communities: an increase in productivity promotes traits related to competitiveness, and an increase in disturbance selects for regenerative traits. Plant persistence, characterised by canopy height, plant growth rate or capacity for vegetative growth express plant competitive abilities, while characteristics such as life span, seed production, seed mass and soil seed bank type describe regenerative abilities (Knevel et al. 
Table 1 Functional ecology of plant traits (changed after Knevel et al. 2005) and life strategies, and their expected and detected responses to degradation

\begin{tabular}{|c|c|c|c|c|c|c|c|}
\hline \multirow{3}{*}{$\begin{array}{l}\text { Plant traits } \\
\text { Life strategy }\end{array}$} & \multirow[t]{3}{*}{ Functional ecology } & \multicolumn{6}{|c|}{ Stage of degradation } \\
\hline & & \multicolumn{3}{|c|}{ Expected } & \multicolumn{3}{|c|}{ Summary results } \\
\hline & & $\begin{array}{l}\text { Fen } \\
\text { S }\end{array}$ & $\begin{array}{l}\text { Fen } \\
\text { meadow } \\
\text { C }\end{array}$ & $\begin{array}{l}\text { Degraded } \\
\text { meadow } \\
\mathrm{R}\end{array}$ & Fen & $\begin{array}{l}\text { Fen } \\
\text { meadow } \\
\text { C }\end{array}$ & $\begin{array}{l}\text { Degraded } \\
\text { meadow } \\
\mathrm{R}\end{array}$ \\
\hline \multicolumn{8}{|l|}{ Persistence } \\
\hline Canopy height & Competitive ability & - & + & & & & \\
\hline Specific leaf area (SLA) & Growth rate, competitive ability & - & + & + & & & \\
\hline $\begin{array}{l}\text { Clonal traits: perennial bud } \\
\text { bank (presence) or/and } \\
\text { belowground bud bank } \\
\text { (presence and size) }\end{array}$ & $\begin{array}{l}\text { Competitive ability, persistence, } \\
\text { clonal integration, storage, } \\
\text { response to e.g. mowing/grazing }\end{array}$ & + & + & - & ++ & - & - \\
\hline $\begin{array}{l}\text { Clonal traits: seasonal bud } \\
\text { bank (presence) or/and } \\
\text { aboveground bud bank } \\
\text { (presence and size) }\end{array}$ & & & & & - & + & ++ \\
\hline \multicolumn{8}{|l|}{ Regeneration } \\
\hline Plant life span & $\begin{array}{l}\text { Response to disturbance, } \\
\text { establishment, invasiveness }\end{array}$ & + & + & - & + & + & - \\
\hline Seed production & $\begin{array}{l}\text { Response to disturbance, } \\
\text { establishment, dispersal }\end{array}$ & - & + & + & & & \\
\hline Seed weight & $\begin{array}{l}\text { Dispersal, establishment, } \\
\text { seed bank longevity }\end{array}$ & + & \pm & - & & & \\
\hline Seed bank longevity & Generative regeneration, response & - & \pm & + & + & - & ++ \\
\hline Soil seed bank size & to disturbance, restoration & - & + & + & - & + & + \\
\hline Flowering period & $\begin{array}{l}\text { Sensitivity to elimination by } \\
\text { mowing, capability to produce } \\
\text { seeds all season round }\end{array}$ & - & + & + & - & + & ++ \\
\hline
\end{tabular}

Expected responses of persistence and regeneration traits based on: Poorter and Remkes 1990; McIntyre et al. 1995; Grime 2002; Pywell et al. 2003; Diaz et al. 2004

Symbols: + positive selection, - negative selection, \pm diverse response possible, no symbol: unknown, no response found

2005; Violle et al. 2009). The analyses on well-defined traits are more explanatory than these on plant life strategies (sensu Grime 1979), which represent a 'metatrait', an aggregate of various plant characteristics.

The aboveground vegetation and the soil seed bank can strongly differ in their species composition and proportions of species abundance (Hopfensperger 2007; Wellstein et al. 2007). Unclear is whether adult plants and seeds are affected similarly or whether different sets of traits are filtered out during these two life stages. Viable seeds in the soil may mainly belong to species that are adapted to soil disturbances, while species abundant in the aboveground vegetation might be strongly influenced by competitive interactions (Thompson et al. 1998; Grime 2002). Some studies showed that some processes (e.g. type of management) affect the abundance of species functional groups in the seed bank and in the vegetation in a different way (Bekker et al. 1997; Aboling et al. 2009). Changes in composition, longevity and density of the soil seed bank are highly relevant because the seed bank determinates the resilience (Van Andel and Grootjans 2005) and restorability of a community (Bakker et al. 1996; Bekker et al. 1997; Zedler 2000). Based on the above we hypothesize the following:

(1) In the hostile but stable environment of undisturbed fens, we expect mainly slow-growing, stress-tolerant, clonally spreading plants that do not invest much in reproduction: they produce few seeds and form transient seed banks (Grime 2002; Diaz et al. 2004; Moles, and Westoby 2006). 
(2) In fen meadows, we expect an increase in competitive species because community assembly is determined by competitive exclusion (Grime 2002; Kotowski and Van Diggelen 2004). The disturbance level is moderate and rather predictable, and we expect an intermediate investment in reproduction: a moderate amount of seeds and a seed bank consisting mainly of short-term persistent seeds (Bekker 1998a; Falińska 1999). The soil seed bank composition is expected to follow the changes in the aboveground vegetation (Bekker et al. 2000).

(3) Frequent disturbances in severely drained meadows select for species with a ruderal strategy that have a short life cycle and regenerate through seeds (Grime 1979; Thompson et al. 1998; Grime 2002). We expect a large investment in reproduction: many and long-lived seeds (Thompson et al. 1998; Hölzel and Otte 2004). Therefore, at first, the relative number of shortlived seeds (and species) in the soil seed bank will increase and thereafter the number of longlived seed (and species) will increase as a response to more intensive drainage. We assume a shift in life history strategies, from $\mathrm{S}$ (fen) to $\mathrm{C}$ (fen meadow) to $\mathrm{R}$ (degraded meadow), during fen degradation (Grime 1979; Grime 2002).

\section{Questions}

1. How does the plant species composition change in a series from undisturbed fen to degraded meadow?

2. Are similar plant trait combinations favoured in the aboveground vegetation and in the soil seed bank during fen degradation?

3. What traits are filtered for in the two degradation stages?

4. How do the soil seed bank type and seed density in the soil change during fen degradation?

\section{Materials and methods}

Study sites

We used a space-for-time substitution approach (Foster and Tilman 2000) and took three sites that had developed from a similar starting point (groundwater-fed fen) and are all located on deep sedge-moss peat. They differ in intensity of drainage and productivity, mainly due to their land use history.

\section{Undrained fen}

The site Lipsk Fen is situated in the valley of the river Biebrza in North-East Poland $\left(53^{\circ} 42^{\prime} 42^{\prime \prime} \mathrm{N}\right.$, $\left.23^{\circ} 13^{\prime} 44^{\prime \prime} \mathrm{E}\right)$. It is a well-developed soligenous fen and still actively growing mire. The dominant species are Carex lasiocarpa, C. lepidocarpa, C. flava, C. panicea, Menyantes trifoliata, Potentilla palustris and several bryophytes.

\section{Semi-natural fen meadow}

The Gützkower Wiesen in eastern Germany is a slightly drained area of around 60 ha in the valley of the river Peene $\left(53^{\circ} 54^{\prime} 50^{\prime \prime} \mathrm{N}, 13^{\circ} 24^{\prime} 00^{\prime \prime} \mathrm{E}\right)$ fed by upwelling ground water. It was an actively growing mire until the seventeeth century. In the eighteenth to nineteenth century, shallow excavation of peat took place and drainage ditches were constructed. Since the nineteenth century, the area developed into a fen meadow, which is annually mown and currently protected as a nature reserve (Bekker et al. 1997). The vegetation consists of hay meadow communities of the alliance Calthion palustris.

\section{Degraded meadow}

The site Catowanie Fen is situated in central Poland $\left(52^{\circ} 00^{\prime} 40^{\prime \prime} \mathrm{N}, 21^{\circ} 21^{\prime} 00^{\prime \prime} \mathrm{E}\right)$. This site was originally a soligenous mire, covered with fen-moss communities, with Carex lasiocarpa and Menyantes trifoliata as dominant species (Oświt and Dembek 2001). Semi-natural meadows belonging to the Calthion palustris and Alopecurion pratensis alliances developed after reclamation in the 1950-1960s (Rudnicka 1961; Oświt and Dembek 2001). Increasing drainage intensity from the 1990s onwards led to the development of severely degraded meadows on organic soils, dominated by ruderals, weeds and common grassland species such as Festuca rubra, Cardaminopsis arenosa, Urtica dioica, Plantago lanceolata. At present, most of these meadows are abandoned or irregularly mown every few years. 
Vegetation and soil seed bank sampling

Few data exist on seed banks of natural fens and of severely degraded meadows in Central Europe. We carried out vegetation and seed bank analyses of the natural fen, fen meadow and degraded meadow ourselves. We used a simplified abundance scale to record the aboveground vegetation composition: dominant ( $>25 \%$ cover), abundant (between $25 \%$ and $5 \%)$ and present $(<5 \%$ cover $)$. We made 20 vegetation relevées of $5 \times 5 \mathrm{~m}$ in the natural fen and the degraded meadow and 10 in the fen meadow. These relevées had an average species richness of 18 species in the natural fen, 30 in the fen meadows and 28 in the degraded meadow.

The soil seed bank was sampled in the same sites as the vegetation descriptions on ten randomly selected plots $(5 \times 5 \mathrm{~m})$ per site. In each plot, we collected 10 cores per soil layer $(0-5$ and $5-10 \mathrm{~cm})$ and pooled these together per layer. Each plot-sample was analysed as a mixed sample and a total of 0.10 $0.125 \mathrm{~m}^{2}$ was sampled per site. Additionally, we present the results for the $10-15 \mathrm{~cm}$ layer in the fen site because it gives more insight into the seed longevity in the undisturbed situation and such information is absent in the literature or databases. Soil sampling was carried out in July (Polish sites) or in March (German site).

After cold stratification for at least 10 weeks, the soil seed bank was analysed in the greenhouse with the seedling emergence method, following the procedure described by Ter Heerdt et al. (1996). All analysis was conducted in the Netherlands in the same year when the samples were collected. Seedlings were identified, counted and removed every 1-2 weeks, until no further germination was observed (after 1520 weeks). If the identification of seedlings to the species level was impossible, species were combined in groups, e.g. the group of Carex flava and C.lepidocarpa. Species of Equisetaceae and Orchidaceae were omitted from the analysis, as their diaspores could not be detected with the applied method.

Species strategies and life-history traits

We started our analysis by testing the hypothesis that during fen degradation the dominating species strategy (after Grime 1973, 1974) shifts from S (fen), to C (fen meadow), to $\mathrm{R}$ (degraded meadow).
Identification of CSR strategies per species was taken from Grime et al. (1988) and Grime et al. (2007).

Next, we analysed selected traits that are related to persistence and regeneration (Table 1). The data on canopy height, seed production, seed Longevity Index (LI), seed weight and Specific Leaf Area index (SLA) were derived from the LEDA Traitbase (Knevel et al. 2005). We also classified seed longevity into classes based on our own measurements (see next section). Additional information on canopy height was based on the description in the Polish flora (Rutkowski 1998). Information on life span and flowering period were taken from the Dutch Botanical Database (Centraal Bureau voor de Statistiek 1991). We used data on the flowering period for the western European situation because sufficient information on the central European flora was not available. The information on clonal growth was provided by the CLO-PLA3 database (Klimešová and Klimeš 2005) (Table 5 in Appendix).

\section{Seed bank classification}

We used the longevity classification key for assessing the soil seed bank persistence (Thompson et al. 1997; Bekker et al. 1998a). Species seed banks were classified as 'transient' (seed viability $<1$ year), 'short-term persistent' ( $>1$ year, $<5$ year) or 'longterm persistent' ( $>5$ year). If the species were absent from the present vegetation, but were found in the seed bank, we assessed the seed longevity by using older vegetation records to determine when species were present at the site (Lipsk Fen 1994-2004; Całowanie Fen 2001-2002).

Data processing and statistical analysis

The similarity in species composition of the several degradation phases was analysed with a Detrended Correspondence Analysis (DCA) (CANOCO 4.5 for Windows), based on re-classified data (Table 5 in Appendix).

In a pre-analysis, we explored the correlation between traits in all the species occurring in the data set by using non-parametric Spearman Rank Order correlation coefficients (Statistica 7). We considered only strongly significant correlations $(P<0.0001)$ as meaningful in the analyses. We linked the data on species composition and abundance per plot and the 
species trait characteristics by transposing the sample-species matrix (taking samples as species and species as samples), and used the traits directly as predictors in a multivariate analysis (CANOCO 4.5 for Windows). Missing trait values for individual species were substituted with an overall average for all species on this trait to avoid zero values and to minimise the impact on the results (see also De Bello et al. 2005). No further data transformations were applied. The relation between species traits and species composition was analysed with a Canonical Correspondence Analysis (CCA). The factors were chosen in a forward selection procedure and tested with a Monte Carlo permutation test for significance $(P<0.05)$. In this analysis, we used only the clonal traits that explained most of variability in the data in the CCA pre-analysis (aboveground and belowground bud bank, seasonal and perennial bud bank, total size of the bud bank). This restriction was necessary because of a high intercorrelation between the clonal traits (Lepš and Šmilauer 2003).

We analysed the relation between trait combinations and species combinations separately for aboveground vegetation and seed bank. Because different strategies and traits may operate during a productivity increase from fen to fen meadow and during a disturbance increase from fen meadow to degraded meadow transition, we repeated the analysis for those two stages separately.

We tested for differences in seed density and abundance in persistence classes between communities with one-way ANOVA (Statistica 7).

\section{Results}

Vegetation and soil seed bank changes during fen degradation

We found differences in species composition between the degradation stages, both in the soil seed bank and in the aboveground vegetation (Fig. 1). We found that both the vegetation and the seed bank samples were arranged in a sequence from fen via fen meadow to degraded meadow (Fig. 1). In the less disturbed stages, we did observe large differences in species composition and abundance between the soil seed bank and the aboveground vegetation but these differences decreased with degradation intensity.

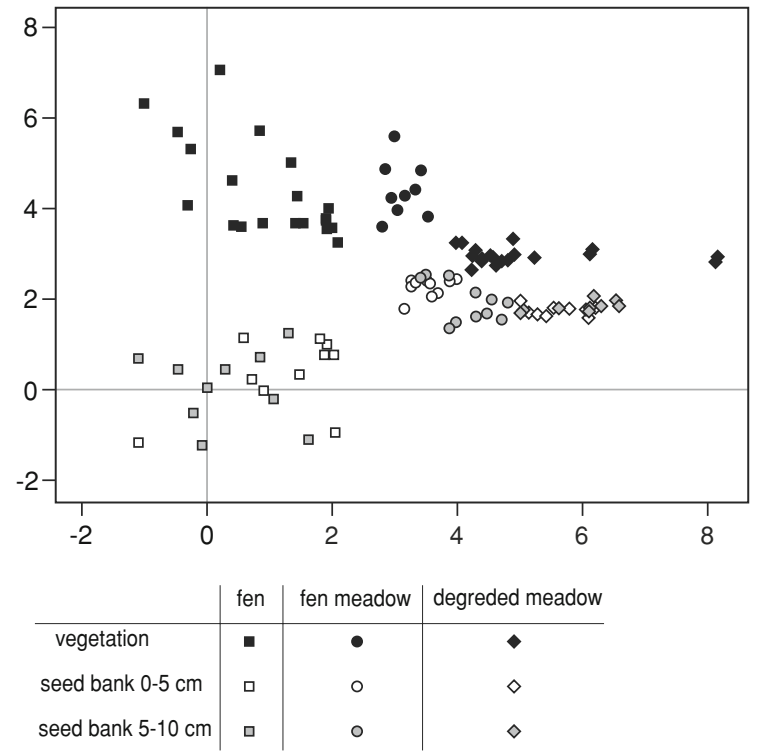

Fig. 1 DCA of the aboveground vegetation and the soil seed bank data for three sites. First axes: $\lambda=0.77$; percentage variance explained $=13 \%$, gradient length 8.2. Second axes: $\lambda=0.37$, cumulative variance explained $=19.3 \%$, gradient length 7.2

We confirmed the hypothesized shift in the dominating plant life strategies, both in the vegetation and in the soil seed bank. The contribution of Sstrategy plants was decreasing, while that of $\mathrm{R}$ strategy plants was increasing during degradation. The relative abundance of $\mathrm{C}$-strategy plants was highest in the fen meadow stage (Table 2). The first two ordination axes explained $8.1 \%$ of the variance in the vegetation data and $9.0 \%$ in the seed bank data.

Correlations between life strategies, abiotic conditions and plant traits

The S-strategy was positively correlated with the length of the life cycle and the size of the perennial bud bank, and negatively correlated with the flowering period, LI, SLA and the size of seasonal bud bank (Table 3). The C-strategy was positively correlated with canopy height and life span. The R-strategy was negatively correlated with life span, canopy height, presence of a perennial bud bank, lateral spread and size of a belowground bud bank, while positively correlated with flowering period, LI, SLA and seasonal bud bank. We found a positive correlation between the clonal traits ( $\rho$ between 0.33 and 0.66 ), with an exception of the size of the seasonal bud bank (Table 3 ). 
Table 2 The effect of the plant strategies on species composition of the three sites that represent fen degradation stages

\begin{tabular}{|c|c|c|c|c|}
\hline \multicolumn{5}{|l|}{ Traits } \\
\hline Vegetation & $F$ & $P$ & $\begin{array}{l}\text { Cumulative explained } \\
\text { of } 0.347\end{array}$ & $\begin{array}{l}\% \text { variance } \\
\text { explained }\end{array}$ \\
\hline \multicolumn{5}{|l|}{ Test } \\
\hline$S$ & 6.98 & 0.002 & 0.212 & 5.2 \\
\hline $\mathrm{C}$ & 2.58 & 0.004 & 0.289 & 1.9 \\
\hline $\mathrm{R}$ & 1.94 & 0.004 & 0.347 & 1.4 \\
\hline CCA ordination & Axis 1 & Axis 2 & & \\
\hline Eigenvalue & 0.300 & 0.031 & & \\
\hline $\begin{array}{l}\text { Cumulative percentage } \\
\text { of variance }\end{array}$ & 7.4 & 8.1 & & \\
\hline Total inertia & 4.068 & & & \\
\hline Soil seed bank & $F$ & $P$ & $\begin{array}{l}\text { Cumulative explained } \\
\text { of } 0.427\end{array}$ & $\begin{array}{l}\% \text { variance } \\
\text { explained }\end{array}$ \\
\hline \multicolumn{5}{|l|}{ Test } \\
\hline $\mathrm{S}$ & 4.94 & 0.002 & 0.245 & 5.5 \\
\hline $\mathrm{C}$ & 2.07 & 0.006 & 0.346 & 2.3 \\
\hline $\mathrm{R}$ & 1.67 & 0.03 & 0.427 & 1.8 \\
\hline $\mathrm{CCA}$ ordination & Axis 1 & Axis 2 & & \\
\hline Eigenvalue & 0.324 & 0.078 & & \\
\hline $\begin{array}{l}\text { Cumulative percentage } \\
\text { of variance }\end{array}$ & 7.3 & 9.0 & & \\
\hline Total inertia & 4.454 & & & \\
\hline
\end{tabular}

Shifts in species trait spectra and trait combinations in the vegetation and the soil seed bank

The identified traits explain the variability in our data slightly better than the CRS classification (Table 2 and Fig. 2A, B). Six plant traits differed significantly $(P<0.05)$ from random with respect to vegetation composition (Fig. 2A) and five traits with respect to the soil seed bank composition (Fig. 2B). The predictors explained ca. $12 \%$ of the data variability on the first two ordination axes in both cases. The same traits that explained the species composition of the aboveground vegetation best did so for the soil seed bank. The significant traits explained cumulatively 0.573 out of 0.707 (vegetation) and 0.623 out of 0.952 (seed bank) of the variance ascribed to all traits included in the analysis.

Plants with a longer flowering period became more abundant during fen degradation. We also found more species with highly persistent seeds in the course of degradation, whereas species forming large perennial and belowground bud banks became less abundant. Species forming seasonal and aboveground bud banks were more abundant in the degraded meadow than in other meadow types (Fig. 2A). Life span was identified as a significant trait, but contributed least to the explanation of the species composition. Generally, natural fens and fen meadows were occupied by perennial species, while annuals were becoming more abundant in degraded meadows.

Shifts in species trait spectra and trait combinations in two degradation stages

The analysis of the two transitions separately showed the same changes in species composition and associated trait combinations (Table 4). During the change from fen to fen meadow, species with a longer flowering period and forming seasonal bud banks increased their abundance. Belowground, we detected 


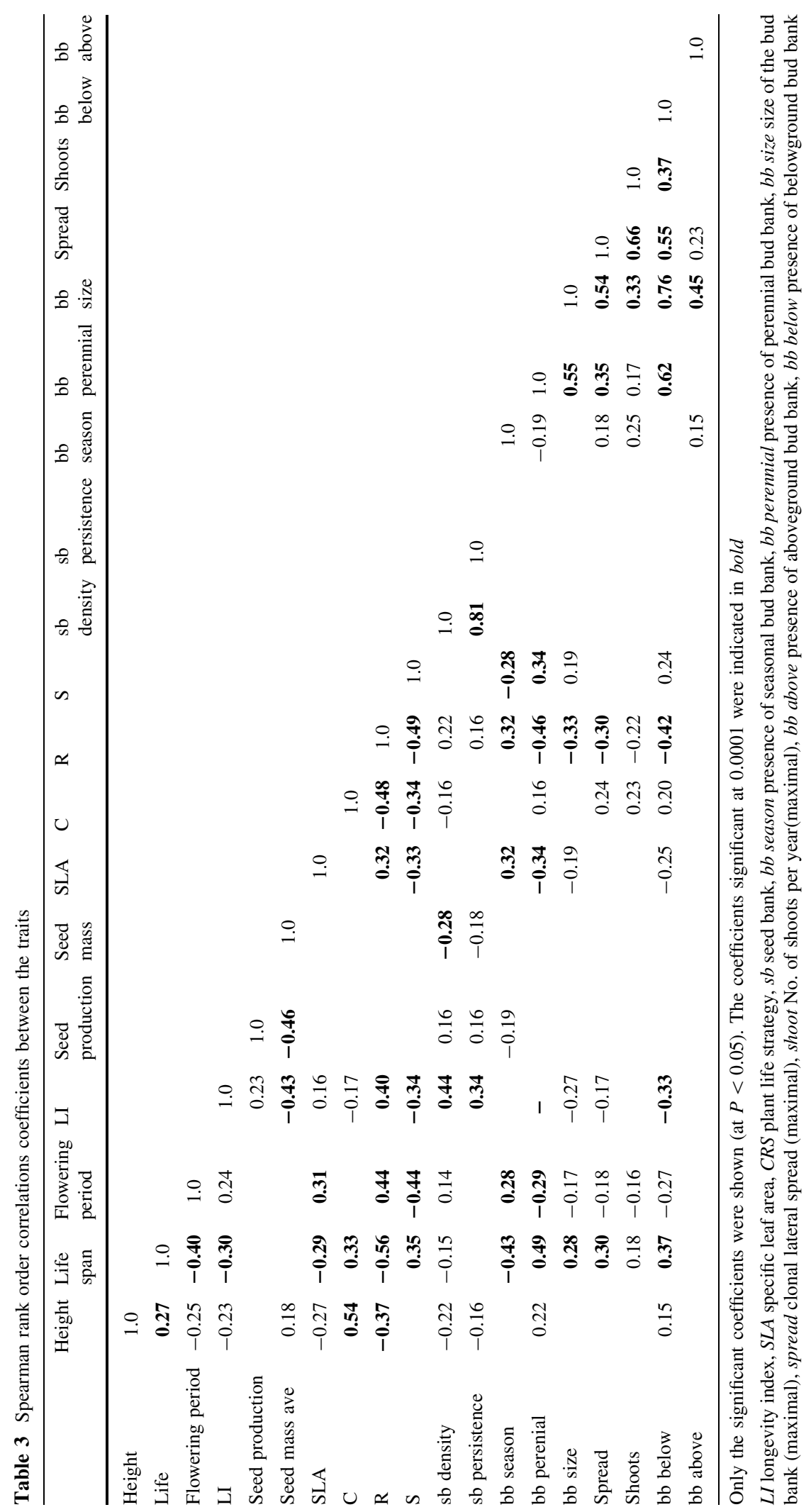



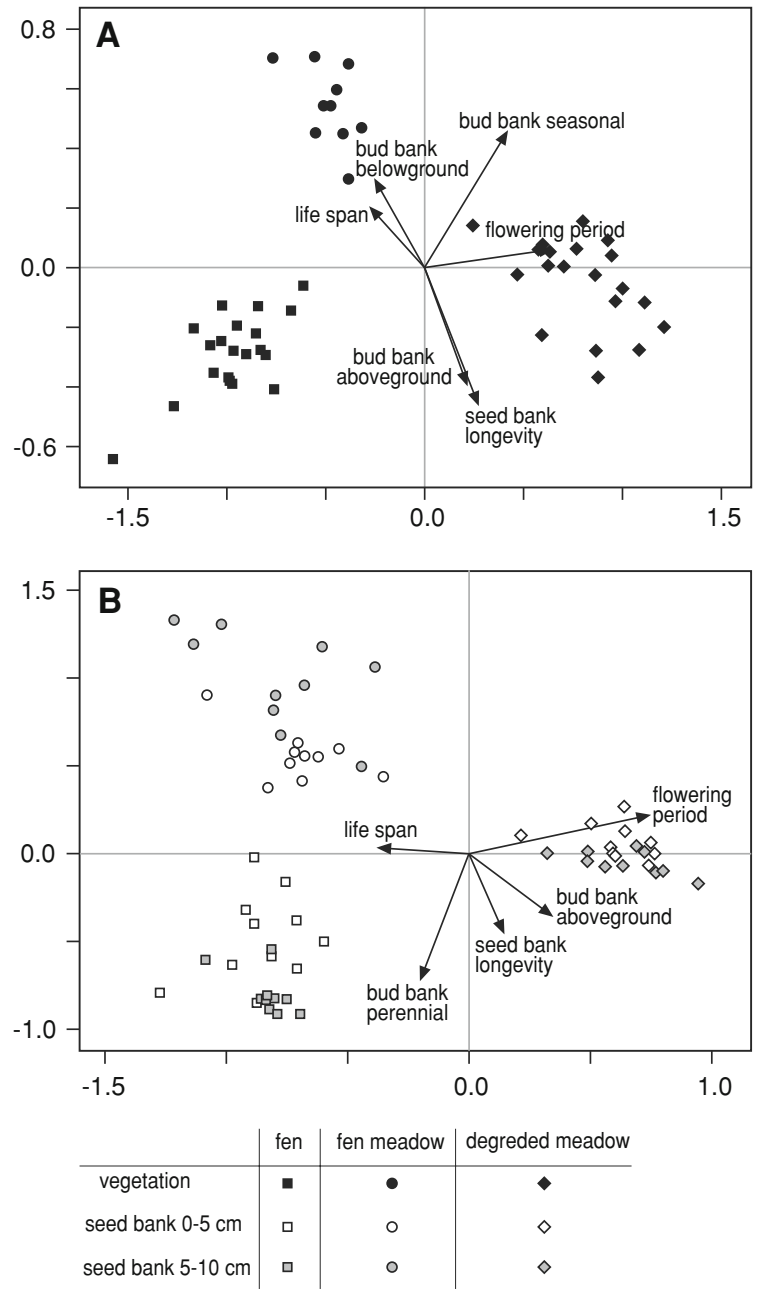

Fig. 2 CCA of the vegetation $(\mathbf{A})$ and the soil seed bank $(\mathbf{B})$ in relation to plant traits (arrows). A: First axes: $\lambda=0.40$; percentage variance explained $=9.8 \%$; second axes: $\lambda=0.09$, cumulative variance explained $=12 \%$. Total inertia 4.119 . B: First axes: $\lambda=0.34$; percentage variance explained $=7.8 \%$; second axes: $\lambda=0.18$, cumulative variance explained $=$ $11.9 \%$. Total inertia 4.33

a decrease in species with a perennial bud bank and an increase in these with a shorter life span and a persistent seed bank. During the change from fen meadow to degraded meadow, we observed in the aboveground vegetation an increase of species with the following traits: long flowering period, long-living seeds, numerous aboveground buds and few belowground buds. Similarly, in the soil seed bank we found more species with a long flowering period, forming many aboveground buds and long-term persistent seeds.
The soil seed bank type and seed density in response to fen degradation

We observed an increase in soil seed bank density during fen degradation. The seed density in the fen site was 35,304 seeds $\mathrm{m}^{-2}$ and increased to 57,550 seeds $\mathrm{m}^{-2}$ and 49,454 seeds $\mathrm{m}^{-2}$ in the fen meadow site and the degraded meadow, respectively (Fig. 3). Both in the fen and in the degraded meadow there were less seeds present in the top soil layer than in the deeper layer (Table 6 in Appendix). We recorded 57 species in the fen (50 and 29 in the aboveground vegetation and soil, respectively), 75 species in the fen meadow (62 and 40 in the aboveground vegetation and soil respectively) and 76 species in the degraded meadow (62 and 50 in the aboveground vegetation and soil, respectively). In total, we recorded 148 species (132 in the vegetation, 90 in the soil seed bank).

The dominant seed bank type changed during the degradation (Fig. 3). The majority of seeds in the fen site belonged to the long-term persistent type, but only a few species dominated (Juncus articulatus $72 \%$, Carex elata 8\%, Carex flava + C. lepidocarpa $6 \%$ ), while others, mostly transient species were hardly found. Also in deeper soil layers $(10-15 \mathrm{~cm})$ there were still many viable seeds $\left(7,491\right.$ seeds $\left.\mathrm{m}^{-2}\right)$ present (mainly Juncus articulatus and several Carex species). Many species typical for fens (e.g. Menyantes trifoliata, Potentilla palustris) occurred in the vegetation only. Also, the seed bank of the fen meadow contained hardly any seeds of transient species, but in contrary to the previous situation the majority of the seeds here belonged to the short-term persistent category (Fig. 3). The density of the shortterm persistent seeds under fen meadow was significantly higher than in the other communities ( $F=67.84, P<0.0001)$. The seed bank of the fen meadows was dominated by Juncus sp., Deschampsia cespitosa and Ranunculus repens (together $85 \%$ of seeds). No other taxa reached above $5 \%$ of the total seed density. The seed bank of the degraded meadow consisted mainly of ruderal species with long-term persistent seeds. Again, only a few species dominated the seed bank. These were mainly species related to soil disturbance: Cardaminopsis arenosa (22\%), Sagina procumbens (21\%), Juncus articulatus (11\%), Cerastium holosteoides (7\%), Capsella bursa-pastoris $(6 \%)$ and Plantago intermedia (6\%). The density of the long-term persistent seed bank in the degraded 
Table 4 The effect of the plant traits on species composition during two degradation transitions

\begin{tabular}{|c|c|c|c|c|}
\hline \multicolumn{5}{|l|}{ Traits } \\
\hline Vegetation & $F$ & $P$ & Cumulative explained 0.447 & $\%$ variance explained \\
\hline \multicolumn{5}{|l|}{ Test } \\
\hline \multicolumn{5}{|l|}{ Fen $\rightarrow$ fen meadow } \\
\hline Flowering period & 3.29 & 0.004 & 0.098 & 3.5 \\
\hline Bud bank seasonal & 1.54 & 0.06 & 0.143 & 1.6 \\
\hline CCA ordination & Axis 1 & Axis 2 & & \\
\hline Eigenvalue & 0.118 & 0.025 & & \\
\hline Cumulative percentage of variance & 4.2 & 5.1 & & \\
\hline Total inertia & 2.835 & & & \\
\hline \multicolumn{5}{|l|}{ Test } \\
\hline Fen meadow $\rightarrow$ degraded meadow & & & Cumulative explained of 0.490 & \\
\hline Flowering period & 6.09 & 0.002 & 0.138 & 5.7 \\
\hline Seed bank longevity & 4.15 & 0.002 & 0.229 & 3.8 \\
\hline Bud bank aboveground & 2.23 & 0.008 & 0.277 & 2.0 \\
\hline Bud bank belowground & 1.85 & 0.03 & 0.317 & 1.7 \\
\hline CCA ordination & Axis 1 & Axis 2 & & \\
\hline Eigenvalue & 0.275 & 0.022 & & \\
\hline Cumulative percentage of variance & 11.5 & 12.4 & & \\
\hline Total inertia & 2.398 & & & \\
\hline Soil seed bank & $F$ & $P$ & Cumulative explained 0.949 & $\%$ variance explained \\
\hline \multicolumn{5}{|l|}{ Test } \\
\hline \multicolumn{5}{|l|}{ Fen $\rightarrow$ fen meadow } \\
\hline Bud bank perennial & 4.83 & 0.002 & 0.264 & 7.8 \\
\hline Life span & 1.76 & 0.02 & 0.359 & 2.8 \\
\hline Seed bank longevity & 1.58 & 0.05 & 0.443 & 2.5 \\
\hline CCA ordination & Axis 1 & Axis 2 & & \\
\hline Eigenvalue & 0.297 & 0.108 & & \\
\hline Cumulative percentage of variance & 8.8 & 12.0 & & \\
\hline Total inertia & 3.378 & & & \\
\hline \multicolumn{5}{|l|}{ Test } \\
\hline Fen meadow $\rightarrow$ degraded meadow & & & Cumulative explained of 0.645 & \\
\hline Flowering period & 4.49 & 0.002 & 0.158 & 5.9 \\
\hline Bud bank aboveground & 3.29 & 0.004 & 0.270 & 4.2 \\
\hline Seed bank longevity & 1.74 & 0.03 & 0.329 & 2.2 \\
\hline CCA ordination & Axis 1 & Axis 2 & & \\
\hline Eigenvalue & 0.274 & 0.039 & & \\
\hline Cumulative percentage of variance & 10.2 & 11.7 & & \\
\hline Total inertia & 2.688 & & & \\
\hline
\end{tabular}




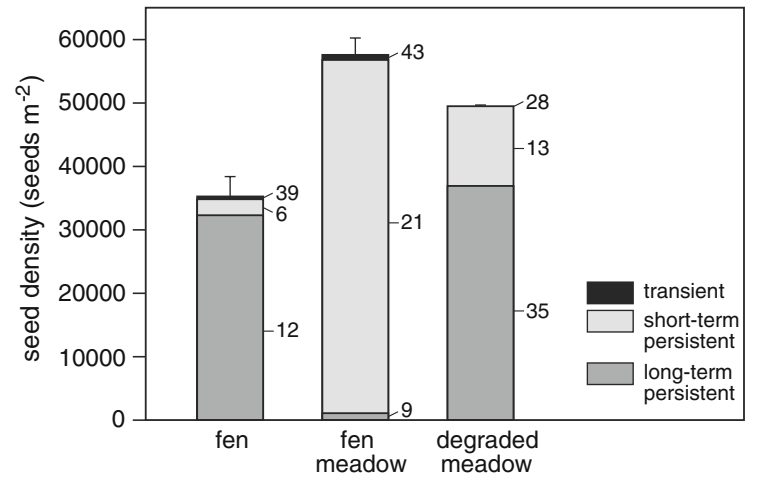

Fig. 3 Soil seed bank density, with respect to the longevity classes, in three sites. Presented data are from $0-10 \mathrm{~cm}$ soil layer. Numbers indicate the number of species. Error bars indicate the sum of the standard deviation of the seed densities of the three seed bank longevity classes in each site

meadow was significantly higher than in the fen meadow $(F=22.42, P<0.0001)$.

\section{Discussion}

We observed changes in the species composition of the vegetation and in the soil seed bank during a sequence of degradation. Overall, generalists (ruderal and common meadow species) replace the habitat specialists (species of fens). The S-strategy plants were gradually replaced by $\mathrm{C}$ - and thereafter by $\mathrm{R}$ strategy plants in the process of degradation, although plant traits were better predictors of the community composition than life strategies. Other authors observed a similar shift from conservative to acquisitive strategies under increasing land-use intensity and nutrient availability (Grime 2002; Diaz et al. 2004; Van Diggelen et al. 2005). We found that species with strong regeneration traits and traits related to resprouting increased during fen degradation. We also found an increase in species with a long flowering period. This suggested that increasing disturbance was an important sieve in species assembly during fen degradation. Similar shifts in species trait spectra were found in the vegetation and in the soil seed bank. Additionally, we found an increasing seed density and increasing proportion of species accumulating shortterm persistent seed banks in the first stage of fen degradation. In the later stage, a seed density and proportion of species accumulating long-term persistent seeds in the soil increased.
In this study, we investigated similar ecosystem types, thus we did not expect a large variability in species traits. A relatively low percentage of the explained variance is normal in this type of analysis (Diaz et al. 2004; Wright et al. 2004, Westoby and Wright 2006). Still, we detected changes in the plant traits combinations, which are related to the species composition during fen degradation.

Changes in spectra of persistence-related traits

We found that species with traits associated with persistence (Knevel et al. 2005) decreased during fen degradation, whereas species with stronger regeneration traits and resprouting abilities increased (Table 1). A response of the regeneration traits to an increasing disturbance was predicted by Lavorel et al. (1997) and Grime (2002).

Vegetative growth, associated with perennial and belowground bud banks, diminished during fen degradation. Kotowski and Van Diggelen (2004) found a similar decrease in the frequency of clonal reproduction from fens to fen meadow communities. Other studies found a preference towards vegetative reproduction in natural fens and permanent grasslands (Van Andel et al. 1993; McIntyre et al. 1995; Van Groenendael et al. 1996). During degradation, clonally reproducing perennials are replaced with generatively reproducing annuals which results in a faster species turnover (Bullock et al. 1995; Ozinga et al. 2007). A selection for seasonal and aboveground buds during fen degradation can be considered as an adaptation to desiccation and seasonal drought, as it allows for quick re-growth after die-off (Klimešová and Klimeš 2007).

We found some correlations between the traits identified in the analysis (Table 3). Many perennial species in (natural or degraded) fen ecosystems produce large perennial and belowground budbank to assure their persistence by clonal growth from the organs hidden below ground, which makes them less vulnerable to aboveground processes, such as mowing or partial die-off of biomass. Perennials also tended to have relatively short flowering period and few seasonal buds, while annual life was associated with long flowering period (for many ruderal species) and numerous seasonal buds. This suggests a tradeoff in allocating the resources in long flowering/seed setting period and a potential for vegetative growth in the following year (see Ozinga et al. 2007). 
We did not find any effects of plant size and SLA. Possibly, this was because these traits are highly variable and differ largely in relation to plant competitive power (Gaudet and Keddy 1988; Wilson et al. 1999; Kotowski and Van Diggelen 2004). SLA may represent the competitive abilities during the seedling stage (Cornelissen et al. 2003; Poorter 2007) and would then be a poor predictor of adult plants or soil seed bank composition.

\section{Changes in spectra of regeneration-related traits}

We found that plant species with persistent seeds increased strongly from natural fen to degraded meadow. We observed that the species of fens and fen meadows have generally transient and short-term persistent seeds, while species of the degraded systems have mainly long-term persistent seeds. The persistent soil seed banks buffer species against local extinction. Ozinga et al. (2009) found that species with the persistent seed banks were less likely to decline, even if the relevant dispersal vectors (especially for species requiring water or animals for dispersal) were lacking. In trait analysis, we did not identify the seed bank density as an important factor during fen degradation. This was probably because it was strongly correlated with the seed bank persistence (Table 3). However, the number of the (persistent) seeds accumulated in the soil strongly increased, especially in the later degradation stage, which causes increased resilience of this system against disturbance (see Hölzel and Otte 2004) as well as against restoration (Van Andel and Grootjans 2005).

Annual species increase at the cost of perennials, especially in a later stage of degradation. This is in agreement with studies by McJannet et al. (1995) and Schippers et al. (2001). Extreme drought probably affects adults more than seeds (Ozinga et al. 2007), leading to an increase in density of persistent seeds. We conclude that regeneration from seeds increases with degree of degradation.

An increase in species with a long flowering period is probably directly linked to a shift in plant strategies: S-plants flower short and late in the season, C-plants flower early, but might flower a second time and R-plants flower early and for a long period. An increase in productivity and the introduction of mowing are believed to favour species flowering and forming seeds early in the season
(Weiher et al. 1999; Pakeman 2004; Van Diggelen et al. 2005; Garnier et al. 2007). Contrary to this, Kotowski and Van Diggelen (2004) and Rasran et al. (2006) found a large variation in the timing and length of the flowering period in fen meadow species. The shift in severely degraded systems towards species flowering longer might be an adaptation to the unpredictable environment. It allows plants to produce seeds when the conditions are favourable or to repeat seed production - for example after plant damage and re-growth (Klimešová and Klimeš 2007) - and these plants eventually produce more seeds. However, we did not find an increase of species with a higher seed production nor with smaller seed weight during degradation.

The clear shift towards regeneration traits suggests that desiccation is the most important driver of community assembly during fen degradation. We did not find a strong response in persistence-related traits, not even in the initial degradation stage. This could be because a productivity increase is limited on extensively used fen meadows with relatively intact hydrological systems. The productivity is enhanced by a higher nutrient availability in an early stage of degradation, but biomass is regularly removed by mowing. Phosphorus availability is low under such conditions and might be reduced further by calcium and iron from mineral-rich groundwater (Lucassen et al. 2005). In a later stage of degradation, the productivity is limited by seasonal water deficits (Banaszuk et al. 1996; Kotowska et al. 1996; Okruszko and Ilnicki 2003) and probably low K-availability (Van Duren et al. 1997; Olde Venterink et al. 2002).

The soil seed bank type and seed density in response to fen degradation

We found that the soil seed bank of the undisturbed fen was dominated by persistent seeds of a few species that are usually not considered to be characteristic for fen mires, while species typical for mires had scarce and transient or short-term persistent seeds. The few data that exist on some of the species showed a similar trend (Bekker et al. 1998a, b; Jensen 1998; Bakker and Berendse 1999; Jansen et al. 2000), although some authors suggested that the seed longevity of such species might increase under cold, anaerobic conditions (Jauhiainen 1998; Matus et al. 
2003; Jensen 2004). Dominance of a few species in the soil seed bank was also observed by other authors (Thompson 1987; Jensen 1998).

We found an increase in density of short-term persistent seeds in fen meadows and an increase of long-term persistent seeds in degraded meadows. This suggests an increasing proportion of species relying on reproduction by seeds. Other authors also observed an increase in generative reproduction in fen meadows compared to fens (Kotowski and Van Diggelen 2004; Fenner and Thompson 2005), possibly at the cost of vegetative reproduction (Ozinga et al. 2007). A high number of persistent seeds in severely disturbed habitats was also found by other authors (Thompson 1992; Touzard et al. 2002; Luzuringa et al. 2005). Often pioneer, weedy and short-lived species almost completely dominate the seed bank of such habitats (Jensen 1998; Hölzel and Otte 2004; Wellstein et al. 2007). We found an increase in similarity between seed bank composition and aboveground vegetation with degradation intensity. This again points to an increasing importance of generative regeneration.

Usually, seed densities in the upper soil layer are higher than in the lower layer (Thompson et al. 1997; Smith et al. 2002). We observed the opposite tendency in fens and degraded meadows. The lower density in fens might be related to the soil structure. The structure of the upper layer is so loose that it is likely that most seeds migrate quickly to deeper layers. To some degree, the same is true for the top soil layers of degraded meadows, but the seeds have to face another problem as well here. The upper layer of severely drained organic soils is often extremely dry and overheated (Succow and Joosten 2001) and many seeds in this layer probably die off. Our own data and longevity classification described the patterns in species composition better than the Longevity Index, probably due to few records from diverse habitats available in the database.

Consequences for vegetation development and relevance for restoration

Our results show a shift from a situation where persistence-related traits dominate to a situation where the regeneration strategy prevails. Species with a longer flowering period, a persistent seed bank and forming numerous seasonal and aboveground buds increased their abundance, whereas those with a shorter flowering period, a transient or short-term persistent seed banks and a low resprouting capacity decreased. Similar trait combinations were promoted in the two stages of the degradation.

Almost the same set of traits influenced species composition in the vegetation and in the soil seed bank during fen degradation. This point to the conclusion that environmental factors, such as disturbance, influence the vegetation and the seed bank in a similar way. The soil seed banks follow an aboveground situation, not only in terms of species composition (Bekker et al. 2000), but also in filtering for the same trait shifts during fen degradation. A possible reason for this is an increasing rate of species turnover during degradation, followed by increasing similarity of the vegetation and the soil seed bank composition (see Fig. 1). Consequently, the functional diversity is not preserved in the soil seed banks during fen degradation, thus cannot facilitate community assembly after restoration.

Plant traits of species of severely degraded meadows were very similar to these represented by other species associations, for example weed communities on arable fields, which are subject to frequent and intensive disturbances (Lososová et al. 2006). The unpredictability and severity of conditions in disturbed meadows is also to some degree similar to those in fireprone ecosystems. However, resprouting and propagule persistence there were probably filtered independently (Pausas and Verdu 2005; Pausas et al. 2006). Nevertheless, it is likely that there is a trade-off between resprouting ability and other plat traits such as size that are more directly affected by site productivity (Pausas and Verdu 2005; Vesk 2006). Altering disturbance regimes was identified as one of the factors responsible for drastic changes in ecosystem states. This was described for various terrestrial and aquatic environments (Scheffer and Carpenter 2003), where the disturbance facilitate a self-maintenance of a newequilibrium system. We suspect that shifts in trait spectra, similar to these that we found, could be responsible for changes in ecosystem states in some systems. The analysis of trait spectra shifts could give an insight in such transformation processes. 
In the extreme environment of severely degraded fens (Succow and Joosten 2001), selection forces may allow only for persistent ruderal species, because there are no other species adopted to such conditions available in the local species pool. This might imply that this system is open to further change, e.g. if welladapted, exotic species will arrive. Under such conditions plant with different sets of traits could increase and dominate in future. Funk et al. (2008) pointed to the importance of revealing the environmental filters and functional traits that decide about the species reassembly after restoration, in order to design systems resistant to invasions by non-native species. However, mainly traits related to persistence and resource use were identified as a key characteristics discriminating between invasive and non-invasive species, even though on the larger spatial scales, the disturbance intensity and seed density rather then competition tend to control the species composition (Funk et al. 2008).

A strong selection in degraded meadows for plants with a persistent seed bank or resprouting abilities may increase the chances for legacy effects (Cousins and Eriksson 2002). This would considerably hamper the prospects for restoration of degraded meadows and it may take a long time to reach a level of biodiversity that is considered a target. The restoration efforts on fen meadows could be enhanced by elimination of the disturbance factors (Funk et al. 2008; Klimkowska et al. 2009). Understanding the shifts in trait spectra during the system degradation and use of species re-assmably could be crucial for restoring resilient and invasion-resistant ecosystems (Pywell et al. 2003; Funk et al. 2008).

Acknowledgment This project was possible thanks to funding from the Prins Bernhard Cultuurfonds (the Netherlands), the Pin-Matra project 'Multifunctional use of Polish peatlands - a chance for preservation of biodiversity' (the Netherlands) and support of the Wetlands Conservation Centre CMOK (Poland). We thank Helena Bartoszuk from Biebrza National Park (Poland) for help in the data collection, John Hodgson for providing data on CRS strategies and Henk de Vries (It Fryske Gea, the Netherlands) for assistance. We thank Jan Kania (Institute for Land Reclamation and Grassland Farming, Poland) and Sylvia den Held (Wageningen University, the Netherlands) for help in field sampling. We thank Jacob Hogendorf and Harold Steendam for assistance in the seed bank analyses and Sigfried Schneider and Iris Van Duren for data collection at the Gützkower Wiesen. Verena Cordlandwehr (University of Groningen) helped by commenting on the text.

Open Access This article is distributed under the terms of the Creative Commons Attribution Noncommercial License which permits any noncommercial use, distribution, and reproduction in any medium, provided the original author(s) and source are credited.

\section{Appendix}

See Tables 5 and 6 
Table 5 The variables, traits and data re-coding used in the analyses

\begin{tabular}{|c|c|c|c|}
\hline Trait & Variables & Scale & Re-classification \\
\hline & $\begin{array}{l}\text { Vegetation species composition and } \\
\text { abundance }\end{array}$ & $\begin{array}{l}\text { Ordinal, semi- } \\
\text { logarithmic }\end{array}$ & $\begin{array}{l}\text { Absent }=0,<5(10) \%=1 \\
\quad<25 \%,>5(10) \%=2,>25 \%=3\end{array}$ \\
\hline & $\begin{array}{l}\text { Seed bank species composition and } \\
\text { abundance }\end{array}$ & $\begin{array}{l}\text { Ordinal, semi- } \\
\text { logarithmic }\end{array}$ & $\begin{array}{l}\text { Absent }=0,1-10 \text { seeds } \mathrm{m}^{-2}=1 \\
\quad \begin{array}{l}11-100=2,101-1000 \\
\quad=3,>1000=4\end{array}\end{array}$ \\
\hline Strategy CRS & Value for $\mathrm{C}, \mathrm{R}, \mathrm{S}$ & Fuzzy coding & Decimal values, $\mathrm{C}+\mathrm{R}+\mathrm{S}=1$ \\
\hline \multicolumn{4}{|l|}{ Persistence } \\
\hline \multirow[t]{2}{*}{ Canopy height } & Value canopy height (m) & Continuous & Average height \\
\hline & $\begin{array}{l}\text { Presence of seasonal bud bank } \\
\text { Presence of perennial bud bank } \\
\text { Size of bud bank (max.) }\end{array}$ & $\begin{array}{l}\text { Categorical } \\
\text { Categorical } \\
\text { Ordinal }\end{array}$ & $\begin{array}{l}\text { No }=0, \text { yes }=1 \\
\text { No }=0, \text { yes }=1 \\
0=0,1-10=1,>10=2\end{array}$ \\
\hline \multirow[t]{4}{*}{ Clonal growth } & $\begin{array}{l}\text { Clonal lateral spread }\left[\mathrm{cm} \text { year }{ }^{-1}\right] \\
\quad(\text { maximal) }\end{array}$ & Ordinal & $\begin{array}{l}\text { Non }=0,<0.01 \mathrm{~cm}=1 ; 0.01- \\
\quad 0.25=2,>0.25=3\end{array}$ \\
\hline & No. of shoots year ${ }^{-1}$ (maximal) & Ordinal & $<1=0 ; 1=1 ; 2-10=2 ;>10=3$ \\
\hline & Presence of bud bank aboveground & Ordinal & $0=0,1-10=1,>10=2$ \\
\hline & Presence of bud bank belowground & Ordinal & $0=0,1-10=1,>10=2$ \\
\hline \multicolumn{4}{|l|}{ Regeneration } \\
\hline Life span & Annuals, biannual, perennials, etc. & Ordinal & $\begin{array}{l}\text { Annual }=1, \text { biannual }=2, \\
\text { three-years }=3, \text { four-years }= \\
4, \text { perennial (longer) }=6, \\
\text { woody }=7\end{array}$ \\
\hline Seed production & $\begin{array}{l}\text { Value seed production per year } \\
\text { per individual }\end{array}$ & $\begin{array}{l}\text { Ordinal, semi- } \\
\text { logarithmic }\end{array}$ & $\begin{array}{l}1-100 \text { seeds per } \\
\text { year per individual }=1, \\
100-1000=2 \\
1000-10000=3,>10000=4\end{array}$ \\
\hline \multirow[t]{2}{*}{$\begin{array}{l}\text { Soil seed bank } \\
\text { longevity }\end{array}$} & $\begin{array}{l}\text { Seed persistence (maximal) evaluated } \\
\text { on a bases of field data }\end{array}$ & Ordinal & $\begin{array}{l}\text { Transit }=1, \text { short-term } \\
\text { persistent }=2, \text { long term } \\
\text { persistent }=3\end{array}$ \\
\hline & Longevity index & Continuous & $\begin{array}{l}\text { Value } 0-1 \text {, average of minutes } \\
\text { for } 5 \text { records }\end{array}$ \\
\hline Soil seed bank density & Seed bank size (maximal) & $\begin{array}{l}\text { Ordinal, semi- } \\
\text { logarithmic }\end{array}$ & $\begin{array}{l}\text { Absent }=0,1-10 \text { seeds } \mathrm{m}^{-2}=1 \\
11-100=2,101-1000=3 \\
>1000=4\end{array}$ \\
\hline Seed mass & Value seed weight [mg] & Continuous & Average mass (g) \\
\hline Flowering period & Flowering period (end-start) & Ordinal & $1=1$ month, $2=2$ months, etc. \\
\hline
\end{tabular}




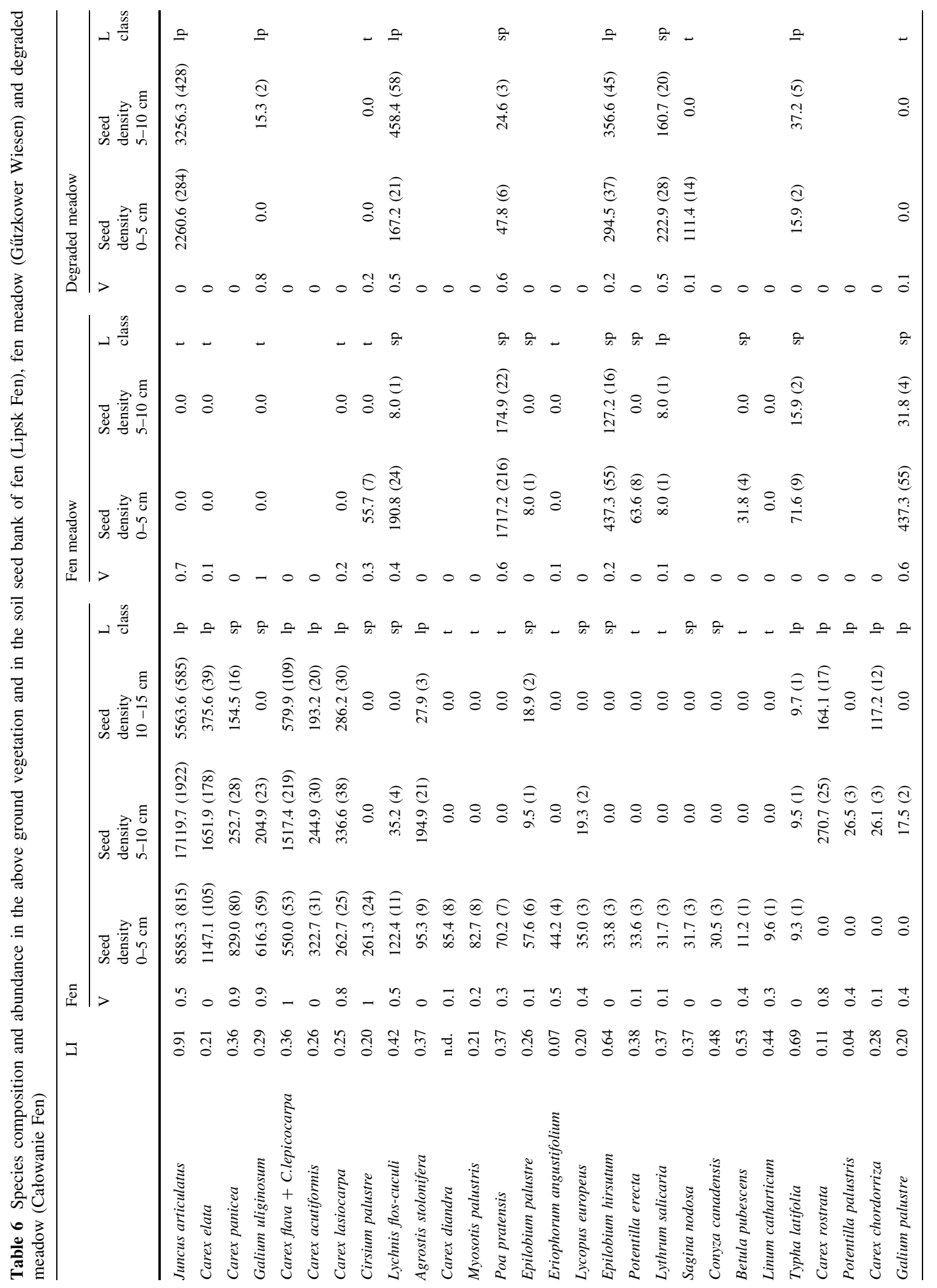




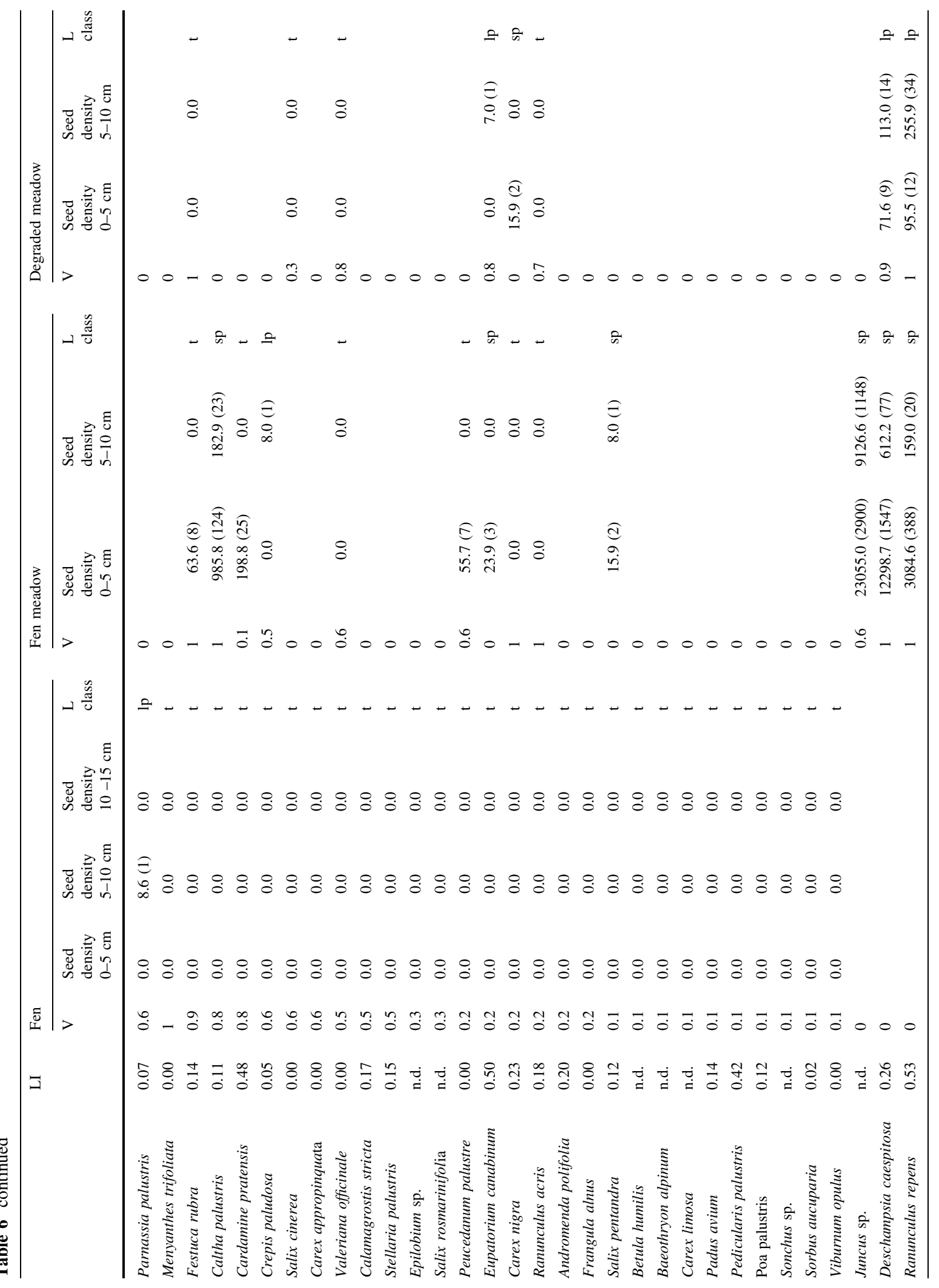




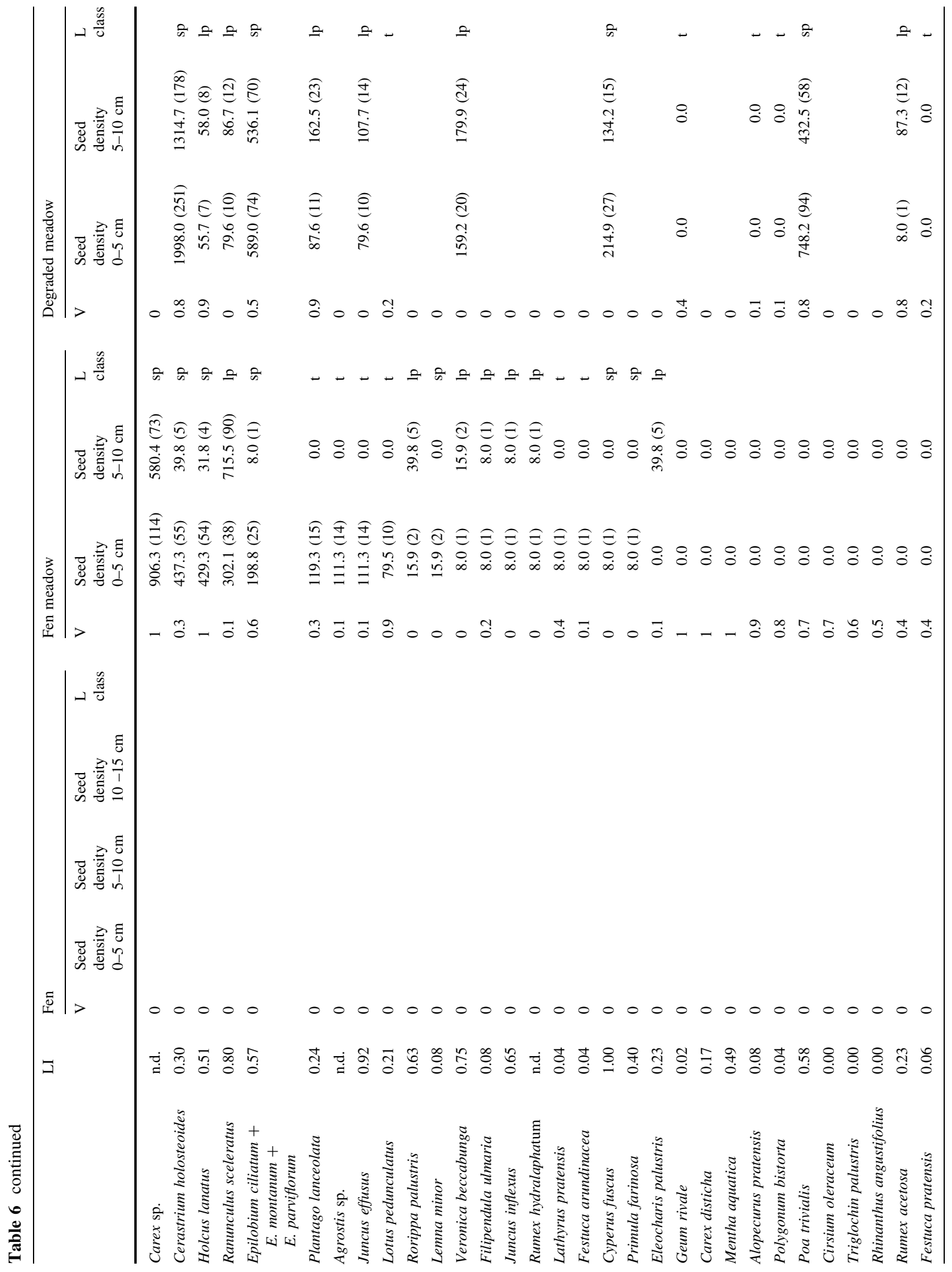




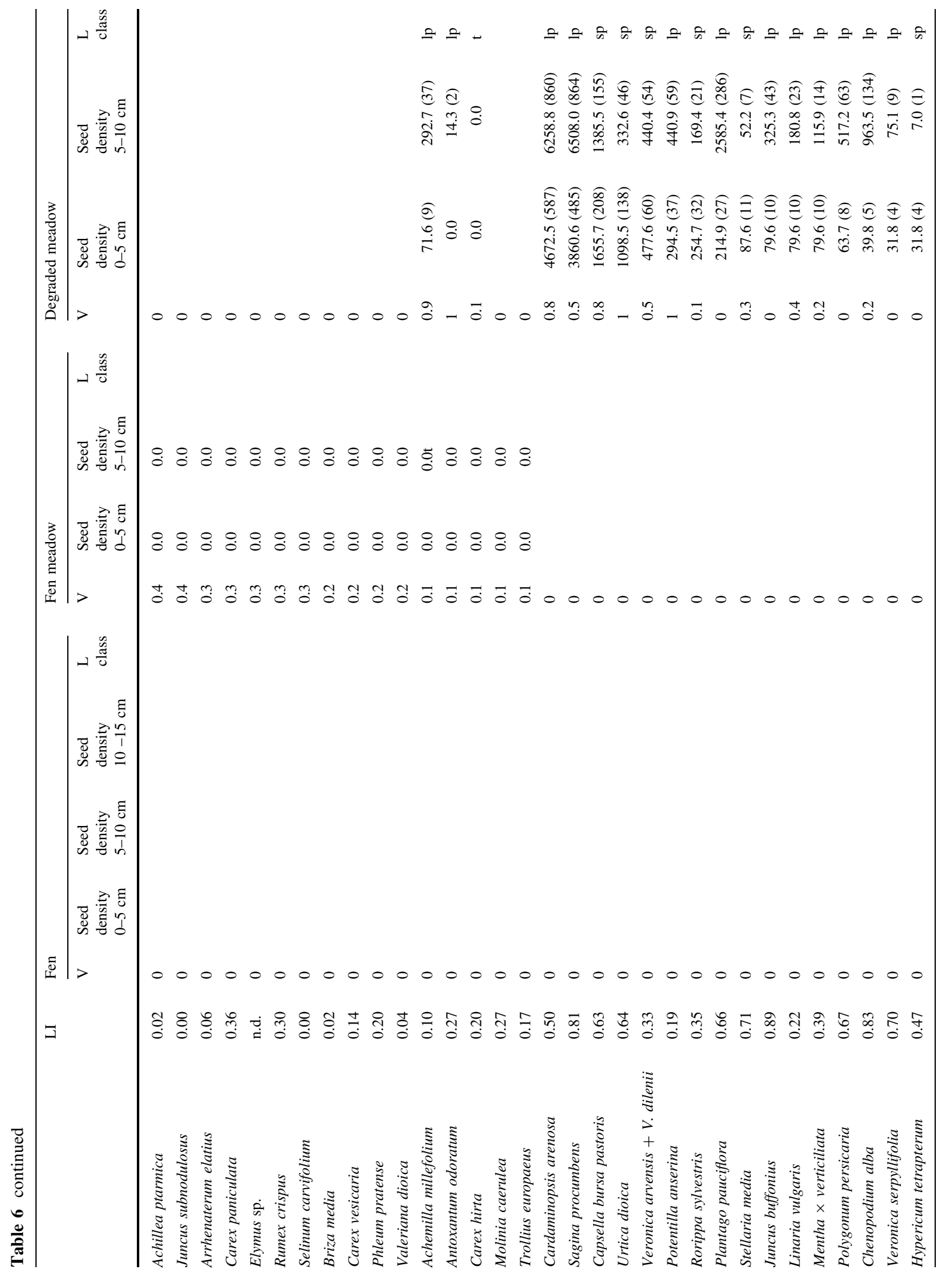




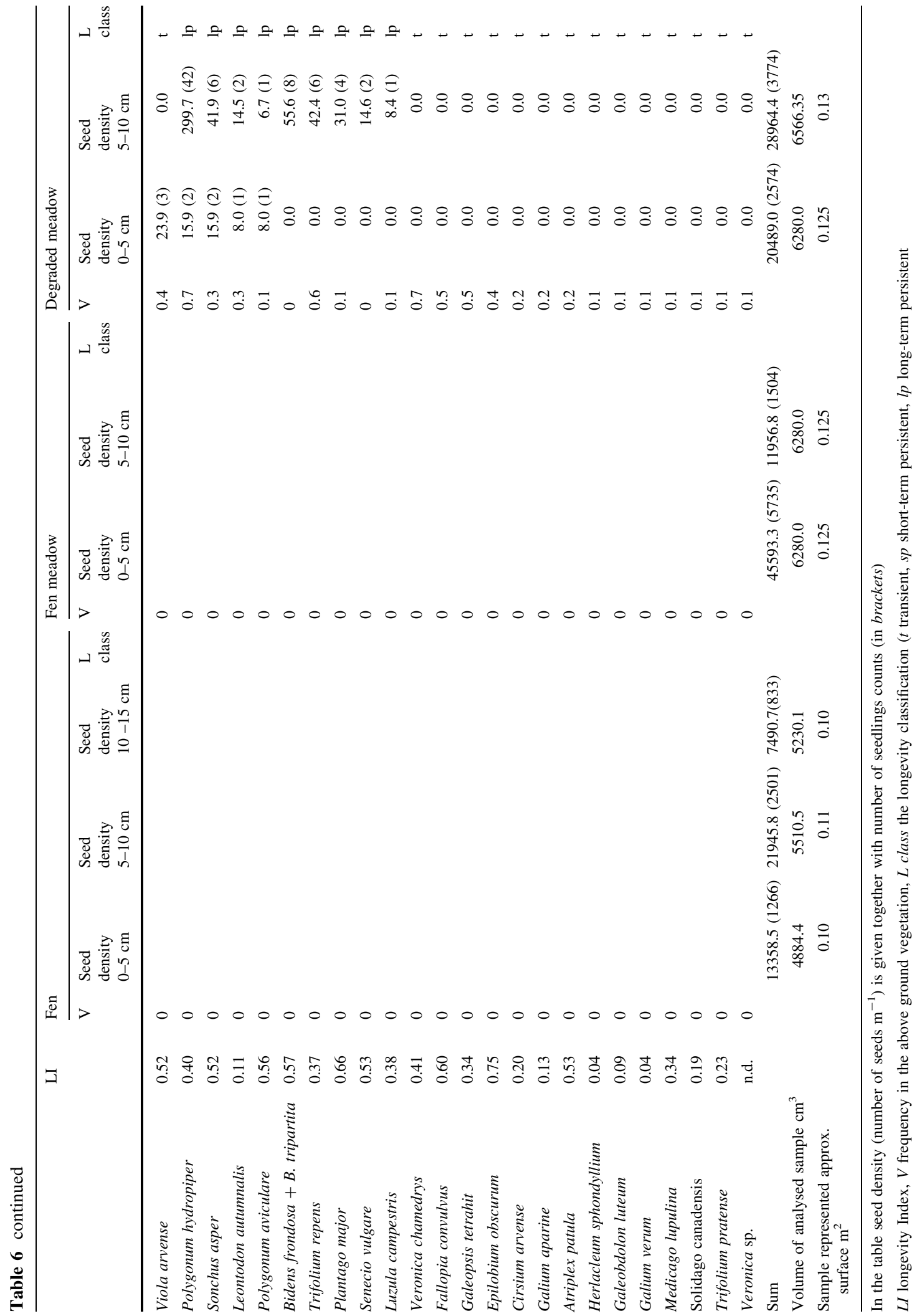




\section{References}

Aboling S, Sternberg M, Perevolotsky A, Kigel J (2009) Effects of cattle grazing timing and intensity on soil seed banks and regeneration strategies in a Mediterranean grassland. J Commun Ecol 9:97-106

Bakker JP, Berendse F (1999) Constraints in the restoration of ecological diversity in grassland and heathland communities. Trends Ecol Evol 14:63-68

Bakker JP, Olff H (1995) Nutrient dynamics during restoration of fen meadow by haymaking without fertilization application. In: Wheeler BD, Shaw SC, Fojt W, Robertson RA (eds) Restoration of temperate wetlands. Wiley, Chichester, pp 143-166

Bakker JP, Poschlod P, Strykstra RJ, Bekker RM, Thompson K (1996) Seed banks and seed dispersal: Important topics in restoration ecology. Acta Bot Neerl 45:461-490

Banaszuk H, Bartoszuk H, Banaszuk P (1996) Wetlands and grasslands of Baiłystok region. In: Characterization and valuation of wetlands and grasslands in Poland in the aspect of natural environmental protection. Project Report, Institute for Land Reclamation and Grassland Farming

Bekker RM, Verwij GL, Smith REN, Reine R, Bakker JP, Schneider S (1997) Soil seed banks in European grasslands: does land use affect regeneration perspective? J Appl Ecol 34:1293-1310

Bekker RM, Bakker JP, Grandin U, Kalamees R, Milberg P, Poschlod P, Thompson K, Willems JH (1998a) Seed size, shape and vertical distribution in the soil: indicators of seed longevity. Funct Ecol 12:834-842

Bekker RM, Schaminée JHJ, Bakker JP, Thompson K (1998b) Seed bank characteristics of Dutch plant communities. Acta Bot Neerl 47:15-26

Bekker RM, Verweij GL, Bakker JP, Fresco LFM (2000) Soil seed bank dynamics in hay field succession. $J$ Ecol 88:594-607

Bullock JM, Hill CB, Silvertown J, Sutton M (1995) Gap colonization as a source of grassland community change: effects of gap size and grazing on the rate and mode of colonization by different species. Oikos 72:273-282

Cornelissen JHC, Cerabolini B, Castro-Díez P, Villar-Salvador P, Montserrat-Martí G, Puyravaud JP, Maestro M, Werger MJA, Aerts R (2003) Functional traits of woody plants: correspondence of species rankings between field adults and laboratory-grown seedlings? J Veg Sci 14:311-322

Cousins SAO, Eriksson O (2002) The influence of management history and habitat on plant species richness in a rural hemiboreal landscape, Sweden. Landsc Ecol 17:517-529

De Bello F, Lepš J, Sebastiá M-T (2005) Predictive value of plant traits to grazing along a climatic gradient in the Mediterranean. J Appl Ecol 42:824-833

De Mars H, Wassen MJ, Peeters WHM (1996) The effect of drainage and management on peat chemistry and nutrient deficiency in the former Jegrznia-floodplain (NE-Poland). Vegetatio 126:59-72

Diaz S, McIntyre S, Lavorel S, Pausas JG (2002) Does hairiness matter in Harare? Resolving controversy in global comparisons of plant trait responses to ecosystem disturbances. New Phytol 154:7-9
Diaz S, Hodgson JG, Thompson K, Cabido M, Cornelissen JHC, Jalili A, Montserrat-Marti G, Grime JP, Zarrinkamar F, Asri Y, Band SR, Basconcelo S, Castro-Diez P, Funes G, Hamzehee B, Khoshnevi M, Pérez-Harguindeguy N, Pérez-Rontomé MC, Shirvany FA, Vendramini F, Yazdani S, Abbas-Azimi R, Bogaard A, Boustani S, Charles M, Dehghan M, de Torres-Espuny L, Falczuk V, Guerrero-Campo J, Hynd A, Jones G, Kowsary E, KazemiSaeed F, Maestro-Martinez M, Romo-Diez A, Shaw S, Siavash B, Villar-Salvador P, Zak MR (2004) The plant traits that drive ecosystems: evidence from three continents. J Veg Sci 15:295-304

Diggelen Van, Middleton B, Bakker JP, Grootjans AP, Wassen MJ (2006) Fens and floodplains of the temperate zone: present status, threats, conservation and restoration. Appl Veg Sci 9:157-162

Falińska K (1999) Seed bank dynamics in abandoned meadows during a 20-year period in the Bialowieza National Park. J Ecol 87:461-475

Faliński JB (1966) Próba określenia zniekształceń fitocenozy. System faz degeneracyjnych zbiorowisk roślinnych. Ekologia Polska 12:31-42

Fenner M, Thompson K (2005) The ecology of seeds. Cambridge University Press, Cambridge

Foster BL, Tilman D (2000) Dynamic and static views of succession: testing the descriptive power of the chronosequence approach. Plant Ecol 146:1-10

Funk JL, Cleland EE, Suding KN, Zavaleta ES (2008) Restoration through reassembly: plant traits and invasion resistance. Trends Ecol Evol 23:695-703

Garnier E, Lavorel S, Ansquer P, Castro H, Cruz P, Dolezal J, Eriksson O, Fortunel C, Freitas H, Golodets C, Grigulis K, Jouany C, Kazakou E, Kigel J, Kleyer M, Lehsten V, Leps J, Meier T, Pakeman R, Papadimitriou M, Papanastasis VP, Quested H, QueTier F, Robson M, Roumet C, Rusch G, Skarpe Ch, Sternberg M, Theau J, Thebault A, Vile D, Zarovali MP (2007) Assessing the effects of land-use change on plant traits, communities and ecosystem functioning in grasslands: a standardized methodology and lessons from an application to 11 European sites. Ann Bot 99:967-969

Gaudet CL, Keddy PA (1988) A comparative approach to predicting competitive ability from plant traits. Nature 334:242-243

Grime JP (1973) Competitive exclusion in herbaceous vegetation. Nature 242:344-347

Grime JP (1974) Vegetation classification by reference to strategies. Nature 250:26-31

Grime JP (1979) Plant strategies and vegetation processes. Wiley, Chichester

Grime JP (2002) Declining plant diversity: empty niches or functional shifts? J Veg Sci 13:457-460

Grime JP, Hodgson JG, Hunt R (1988) Comparative plant ecology. A functional approach to common British species. Unwin Hyman, London, UK

Grime JP, Hodgson JG, Hunt R (2007) Comparative plant ecology. A functional approach to common British species. Castlepoint Press, UK

Hölzel N, Otte A (2004) Inter-annual variations in the soil seed bank of flood-meadows over two years with different flooding patterns. Plant Ecol 174:279-291 
Hopfensperger KN (2007) A review of similarity between seed bank and standing vegetation across ecosystems. Oikos 116:1438-1448

Jansen AJM, Grootjans AP, Jalink HM (2000) Hydrology of Dutch Cirsio-Molinietum meadows: prospects for restoration. Appl Veg Sci 3:51-64

Jasnowski M (1972) Rozmiary i kierunki przeksztalcen szaty roslinnej torfowisk. 'Phytocoenosis' Biuletyn Fitosocjologiczny 1.3. Warszawa-Białowieża (in Polish)

Jauhiainen S (1998) Seed and spore banks of two boreal mires. Ann Bot Fenn 35:197-201

Jensen K (1998) Species composition of soil seed bank and seed rain of abandoned wet meadows and their relation to aboveground vegetation. Flora 193:345-359

Jensen K (2004) Dormacy patterns, germination ecology, and seed-bank types of twenty temperate fen grassland species. Wetlands 24:152-166

Joosten H, Clarke D (eds) (2002) Wise use of mires and peatlands-background and principles including a framework for decision-making. International Mire Conservation Group and International Peat Society. Saarijärven Offset Oy, Saarijärvi, Finland

Kajak A, Okruszko H (1990) Grasslands on drained peats in Poland. In: Breymeyer AI (ed) Ecosystems of the world 17A; managed grasslands. Elsevier Scientific Publications, Amsterdam, The Netherlands, pp 213-253

Keddy PA (1992) Assembly and response rules: two goals for predictive community ecology. J Veg Sci 3:157-164

Klimešová J, Klimeš L (2005) CLO-PLA: databáze architektury klonálního růstu rostlin střední Evropy (CLO-PLA: a database of clonal growth architecture of Central-European plants). Zpr Čes Bot Společ, Praha 20:53-64

Klimešová J, Klimeš L (2007) Bud banks and their role in vegetative regeneration - a literature review and proposal for simple classification and assessment. Perspect Plant Ecol Evol Syst 8:115-129

Klimkowska A, Kotowski W, van Diggelen R, Grootjans AP, Dzierża P, Brzezińska K (2009) Vegetation re-development after fen meadow restoration by topsoil removal and hay transfer. Restor Ecol 17 (in press)

Knevel IC, Bekker RM, Kunzmann D, Stadler M, Thompson K (eds) (2005) The LEDA Traitbase collecting and measuring standards of life-history traits of the northwest European flora. LEDA Traitbase project. University of Groningen, The Netherlands

Kotowska J, Pasternak-Kusmierska D, Wilpiszewska I (1996) Comparative analysis of the sward of hay-growing meadows on peat muck soils. Pol Ecol Stud 22:141-157

Kotowski W, Van Diggelen R (2004) Light as an environmental filter in fen vegetation. J Veg Sci 15:583-594

Kucharski L (2000) Przemiany roslinnosci lakowej w Polsce Srodkowej w wyniku zmian metod gospodarowania. In: Radwan S, Lorkiewicz Z. Problemy ochrony i użytkowania obszarów wiejskich o dużych walorach przyrodniczych, Wydawnictwo Uniwersytetu Marii CurieSklodowskiej, Lublin, pp. 227-234

Kucharski L, Pisarek W (1996) Wetlands and grasslands in the Lodz region. In: Characterization and valuation of wetlands and grasslands in Poland in the aspect of natural environmental protection. Project report, Institute for
Land Reclamation and Grassland Farming, Wydawnictwo IMUZ

Lavorel S, Garnier E (2002) Predicting changes in community composition and ecosystem functioning from plant traits: revisiting the Holly Grail. Funct Ecol 16:545-556

Lavorel S, McIntyre S, Landsberg J, Forbes TDA (1997) Plant functional classification: from general groups to specific groups base on response to disturbance. Trends Ecol Evol 12:474-478

Lenssen JPM, ten Dolle GE, Blom CWPM (1998) The effect of flooding on the recruitment of reed marsh and tall forb plant species. Plant Ecol 139:13-23

Lenssen JPM, Menting FBJ, Van der Putten WH (2003) Plant responses to simultaneous stress of waterlogging and shade: amplified or hierarchical effects? New Phytol 157:281-290

Lepš J, Šmilauer P (2003) Multivariate analysis of ecological data using CANOCO. Cambridge University Press, New York

Lososová Z, Chytrý M, Kühn I, Hájek O, Horáková V, Pyšek P, Tichý L (2006) Patterns of plant traits in annual vegetation of man-made habitats in central Europe. Perspect Plant Ecol Evol Syst 8:69-81

Lucassen ECHET, Smolders AJP, Lamers LPM, Roelofs JGM (2005) Water table fluctuations and groundwater supply are important in preventing phosphate-eutrophication in sulphate-rich fens: consequences for wetland restoration. Plant Soil 269:109-115

Luzuringa AL, Escudero A, Olano JM, Loidi J (2005) Regenerative role of seed banks following an intense soil disturbance. Acta Oecol 27:57-66

Matus G, Verhagen R, Bekker RM, Grootjans AP (2003) Restoration of the Cirsio dissecti-Molinietum in The Netherlands: can we rely on soil seed bank? Appl Veg Sci 6:73-84

McIntyre S, Lavorel S, Tremont RM (1995) Plant life-history attributes: their relationship to disturbance response in herbaceous vegetation. J Ecol 83:31-44

McJannet CL, Keddy PA, Pick FR (1995) Nitrogen and phosphorus tissue concentrations in 41 wetlands plants: a comparison across habitats and functional groups. Funct Ecol 9:231-238

Menge BA, Sutherland JP (1987) Community Regulation: variation in Disturbance, competition, and predation in relation to environmental stress and recruitment. Am Nat 130:730-757

Middleton BA, Holsten B, Van Diggelen R (2006) Biodiversity management of fens and fen meadows by grazing, cutting and burning. Appl Veg Sci 9:307-316

Moles AT, Westoby M (2006) Seed size and plant strategy across the whole life cycle. Oikos 113:91-105

Okruszko H (1957) Zagadnienia degradacji torfowisk na tle wlasnosci fizycznych oraz żyzności torfu. Polska Akademia Nauk, Wydzial Nauk Rolniczych i Lesnych, Zeszyty problemowe postepów nauk rolniczych 10. 'Zmiany w torfowisku wywolane odwodnieniem', Państwowe Wydawnictwo Rolnicze i Leśne, Warszawa

Okruszko H (1977) Differentiation in the ecological conditions of a grassland ecosystem in the Wizna fen as influenced by reclamation. Pol Ecol Stud 3:5-85 
Okruszko H, Ilnicki P (2003) The Moorsh horizonts as quality indicators of reclaimed organic soils. In: Parent L-E, Ilnicki P (eds) Organic soils and peat materials for sustainable agriculture. CRC Press, Boca Raton

Okruszko H, Dembek W, Oświt J (1999) Możliwosci pdniesienia wartosci przyrodniczych Bagna Wizna. In: Dembek W (eds) Aktualna Problematyka Ochrony Mokradeł, Wydawnictwo IMUZ

Oświt J, Dembek W (2001) Geo morfologiczno-hydrologiczne uwarónkowania rozwoju mokradeł na przykładzie torfowiska Całowanie w dolinie środkowej Wisły. Woda Środowisko - Obszary Wiejski 1 (3), Wydawnictwo IMUZ, Falenty

Ozinga WA, Hennekens SM, Schaminée JHJ, Smits NAC, Bekker RM, Römermann Ch, Klimeš L, Bakker JP, Van Groenendael JM (2007) Local above-ground persistence of vascular plants: life history trade-offs and environmental constrains. J Veg Sci 18:489-497

Ozinga WA, Römermann Ch, Bekker RM, Prinzing A, Tamis WLM, Schaminée JHJ, Hennekens SM, Thompson K, Poschlod P, Kleyer M, Bakker JP, van Groenendael JM (2009) Dispersal failure contributes to plant losses in NW Europe. Ecol Lett 12:66-74

Pakeman RJ (2004) Consistency of plant species and trait responses to grazing along a productivity gradient: a multi-site analysis. J Ecol 92:893-905

Pausas JG, Verdu M (2005) Plant persistence traits in fireprone ecosystems of the Mediterranean basin: a phylogenetic approach. Oikos 109:196-202

Pausas JG, Keeley JE, Verdu M (2006) Inferring differential evolutionary processes of plant persistence traits in Northern Hemisphere Mediterranean fire-prone ecosystems. J Ecol 94:31-39

Poorter L (2007) Are species adapted to their regeneration niche, adult niche, or both? Am Nat 169:433-442

Poorter H, Remkes C (1990) Leaf area ration and net assimilation rate of 24 wild species differing in relative growth rate. Oecologia 83:553-559

Pywell R, Bullock JM, Roy DB, Warman L, Walker KJ, Rothery P (2003) Plant traits as predictors of performance in ecological restoration. J Appl Ecol 40:65-77

Rasran L, Vogt K, Jensen K (2006) Seed content and conservation evaluation of hay material of fen grasslands. $J$ Nat Conserv 14:34-45

Rudnicka W (1961) Dokumentacja geologiczna torfowisk Całowanie. Uniwersytet Warszawski, Zakład Systematyki i Geografii Roślin, Warszawa

Rutkowski L (1998) Klucz do oznaczania roślin naczyniowych Polski Niżowej. Wydawnictwo Naukowe PWN, Warszawa

Scheffer M, Carpenter SR (2003) Catastrophic regime shifts in ecosystems: linking theory to observation. Trends Ecol Evol 18:648-656

Schippers P, Van Groenendael JM, Vleeshouwers LM, Hunt R (2001) Herbaceous plant strategies in disturbed habitats. Oikos 95:198-210

Smith RS, Shiel RS, Millward D, Corkhill P, Sanderson RA (2002) Soil seed banks and the effects of meadow management on vegetation change in a 10-year meadow field trial. J Appl Ecol 39:279-293
Sousa WP (1984) The role of disturbance in natural communities. Annu Rev Ecol Syst 15:353-391

Succow M, Joosten H (2001) Landschaftsökologische Moorkunde. Schweizerbart'Sche Verlagsbuchhandlung, Stuttgart

Temperton VM, Hobbs RJ, Nuttle T, Halle S (2004) Assembly rules and restoration ecology: bridging the gap between theory and practice. Society for Ecological Restoration International. Island Press, Washington

Ter Heerdt GNJ, Verweij GL, Bekker RM, Bakker JP (1996) An improved method for seed-bank analysis: seedling emergence after removing the soil by sieving. Funct Ecol 10:144-151

Thompson K (1987) Seed and seed banks. New phytologists 106:23-34

Thompson K (1992) The functional ecology of seed banks. In: Fenner M (ed) The ecology of seeds, regeneration in plant communities. CAB International, Wallingford

Thompson K (1994) Predicting the fate of temperate species in response to human disturbance and global change. In: Boyle TJB, Boyle CEB (eds) Biodiversity, temperate ecosystems and global change. Springer-Verlag, Berlin, Germany, pp 61-76

Thompson K, Bakker JP, Bekker RM (1997) Soil seed banks of North West Europe: methodology, density and longevity. Cambridge University Press, Cambridge

Thompson K, Bakker JP, Bekker RM, Hodgson JG (1998) Ecological correlates of seed persistence in soil in the North-West European flora. J Ecol 86:163-169

Touzard B, Amiaud B, Langlois E, Lemauviel S, Clement B (2002) The relationships between soil seed bank, aboveground vegetation and disturbances in an eutrophic alluvial wetland of Western France. Flora 197:175-185

Van Andel J, Grootjans AP (2005) Concepts in restoration ecology. In: van Andel J, Aronson J (eds) Restoration ecology. The new frontier. Blackwell Publishing, Oxford, pp 16-30

Van Andel J, Bakker JP, Grootjans AP (1993) Mechanism of vegetation succession: a review of concepts and perspectives. Acta Bot Neerl 42:413-433

Van Diggelen R, Sijtsma FJ, Strijker D, van den Burg J (2005) Relating land-use intensity and biodiversity at the regional scale. Basic Appl Ecol 6:145-159

Van Duren IC, Boeye D, Grootjans AP (1997) Nutrient limitations in an extant and drained poor fen: implications for restoration. Plant Ecol 133:91-100

Van Groenendael JM, Klimeš L, Klimešová J, Hendriks RJJ (1996) Comparative ecology of clonal plants. Phil Trans R Soc Biol Sci 351:1331-1339

Venterink HO, Davidsson TE, Kiehl K, Leonardson L (2002) Impact of drying and re-wetting on $\mathrm{N}, \mathrm{P}$ and $\mathrm{K}$ dynamics in a wetland soil. Plant Soil 243:119-130

Verhoeven JTA, Kemmers RH, Koerselman W (1993) Nutrient enrichment of fresh water wetlands. In: Vos CC, Opdam P (eds) Landscape ecology of a stressed environment. Chapman and Hall, London, UK, pp 33-59

Vesk PA (2006) Plant size and resprouting ability: trading tolerance and avoidance of damage? J Ecol 94:1027-1034

Violle C, Garnier E, Lecoeur J, Roumet C, Podeur C, Blanchard A, Navas ML (2009) Competition, traits and resource depletion in plant communities. Oecologia (in press) 
Weiher E, Van der Werf A, Thompson K, Roderick M, Garnier E, Eriksson O (1999) Challenging Theophrastus: a common core list of plant traits for functional ecology. J Veg Sci 10:609-620

Welander J (2000) Spatial and temporal dynamics of wild boar (Sus scrofa) rooting in a mosaic landscape. J Zool 252:263-271

Wellstein C, Otte A, Waldhardt R (2007) Seed bank diversity in mesic grasslands in relation to vegetation type, management and site conditions. J Veg Sci 18:153-162

Westoby M, Wright IJ (2006) Land-plant ecology on the basis of functional traits. Trends Ecol Evol 21:261-268

Wilson PJ, Thompson K, Hodgson JG (1999) Specific leaf area and leaf dry matter content as alternative predictors of plant strategies. New Phytol 143:155-162
Wright IJ, Reich PB, Westoby M, Ackerly DD, Baruch Z, Bongers F, Cavender-Bares J, Chapin T, Cornelissen JH, Diemer M, Flexas J, Garnier E, Groom PK, Gulias J, Hikosaka K, Lamont BB, Lee T, Lee W, Lusk C, Midgley JJ, Navas ML, Niinemets U, Oleksyn J, Osada N, Poorter H, Poot P, Prior L, Pyankov VI, Roumet C, Thomas SC, Tjoelker MG, Veneklaas EJ, Villar R (2004) The worldwide leaf economics spectrum. Nature 428:821-827

Zedler JB (2000) Progress in wetlands restoration ecology. Trends Ecol Evol 15:402-407

Zeitz J, Velty S (2002) Soil properties of drained and rewetted fen soils. J Plant Nutr Soil Sci 165:618-626 